\title{
Removal of Azo and Anthraquinone Dye by Plant Biomass as Adsorbent - A Review
}

\author{
Peck Kah Yeow ${ }^{1}$, Sie Wei Wong ${ }^{1}$, Tony Hadibarata ${ }^{1, *}$ (D) \\ 1 Department of Environmental Engineering, Faculty of Engineering and Science, Curtin University Malaysia, CDT 250, \\ Miri, Malaysia \\ * Correspondence: hadibarata@ curtin.edu.my;
}

Scopus Author ID 16233109100

Received: 2.07.2020; Revised: 20.07.2020; Accepted: 21.07.2020; Published: 22.07.2020

\begin{abstract}
Acting as a key element for the survival of human and nature, clean water also contributes tremendously to the ever-growing industries in a country. However, the supply of clean water had led to a decrease as pollutants such as dyes had caused a major negative impact on pure and clean main water bodies. In recent years, textile industries have developed and contributed to more than $50 \%$ of dye wastewaters in the world. The improper method of discharging dye effluent to the aquatic environment caused the destruction of habitat and degradation of water quality. Advanced treatments such as photocatalysis, electrooxidation, the Fenton process, and biological treatment via bacterium are often used for dye wastewaters. However, these treatment processes are often expensive in operation and maintenance. In conjunction, adsorption is one of the efficient, cost-effective, and environmentally friendly treatment methods. The adsorbent most widely used is the activated carbon adsorbent. Activated carbon comes in two forms, granular activated carbon (GAC) and powdered activated carbon (PAC). There are two methods to activation of carbon that are physical activation and chemical activation. The factors affecting the efficiency of adsorption are the adsorbent dosage, dye concentration, $\mathrm{pH}$ value, and temperature. In this article, the efficiency of dye wastewater treatment via adsorption is discussed. Several waste materials are being studied especially agricultural biomass as it has little or no economic value and often poses disposal issues. Some low-cost agricultural biomassbased adsorbents such as tea waste, hazelnut husk, bacteria aggregate, rice ash, pineapple leaf, and fruit waste have been tested to be effective in the dye removal process. There are mainly four categories of agricultural biomass-derived adsorbent, such as leaf-based, peel-based, stem-based, and seed-based adsorbents.
\end{abstract}

Keywords: Adsorption; Activated carbon; Dye wastewaters; Agricultural waste.

(C) 2020 by the authors. This article is an open-access article distributed under the terms and conditions of the Creative Commons Attribution (CC BY) license (https://creativecommons.org/licenses/by/4.0/).

\section{Introduction}

Life on Earth is highly dependent on clean water as it serves as one of the requirements needed to conduct activities that have huge implications for the daily life chain. To ensure water to have of any beneficial value for human usage, it is required that a good quality of water meets the favorable level of physical and chemical requirements that is comparable to national water quality guidelines. Water pollution is the change of any beneficial use of water due to the existence of any biological, physical, or chemical factors that could lead to a hazardous impact on safety and public health. Dyes have become one of the major pollutants to the environment due to the high amount of discharge of wastewater containing high concentrations of dye. There are various types of dye; however, the most commonly used dye 
is the azo dyes. In textile industries, azo dyes are highly used and have accounted for a minimum of $50 \%$ of the synthetic dyes used in the world. Azo dyes are normally in red, orange, and yellow colors. They are also toxic and can cause recalcitrance and salination of water resources. The high frequency of usage of azo dye also caused the abundance of wastewater in the environment. Hence, it is important to treat dye wastewater before discharging into the environment $[1,2]$. The treatment of dye wastewater can be classified into three categories, which are physical, chemical, or biological methods. However, studies found that some physical and chemical treatments do not mineralize dyes completely, which may cause secondary pollution when discharged into the environment. On the other hand, biological treatments are often recommended in treating dye wastewaters. Biological treatment is coming into a trend as it is cost-effective, eco-friendlier, and produces less sludge compared to physical and chemical treatments. The only downside of biological treatment is the inefficiency of decolorization during treatment. The efficiency of biological treatment often depends on the microorganism used in treatment. There are several methods to classify dyes, and one of them is, according to the manufacturing source of being natural or synthesized. Natural dyes are derived from natural resources, which can be categorized into the plant, animal, mineral, microbial and fungal origins. The majority of natural dyes are extracted from plants, and the parts utilized include leaves, twigs, flowers, bark, roots, fruits, and stems. In 1856, the first synthetic dye named mauve was accidentally created by William Perkin while searching for a cure for malaria. Ever since, more chemical dyes have been discovered and extensively used in industries as synthetic dyes are less expensive and have better color fastness compared to natural dyes. Nevertheless, harmful chemicals are often found in synthetic dyes such as lead, copper, benzene, mercury, and toluene. As shown in Table 1, synthetic dyes can be classified by their types of surfaces to which they can be applied, method of application, and chemical composition [3]. Dyes are also categorized based on their chemical structures, which consist of a group of atoms known as chromophores. Chromophores are organic molecules that absorb light at specific frequencies formed by atoms and electrons, which cause dyes to be colored [4]. There are several chromophores for dyes that are present in the form of azo, anthraquinone, triarylmethane, heterocyclic, indigoid, nitroso, nitro, and phthalein. It is reported that azo dyes are the largest class of dyes being applied in the industries because of the simplicity of the pairing reaction and the extensive possibilities for structural variations to adapt to the needs of complex applications, as shown in Table 2.

Table 1. Types of dyes used on suitable surfaces.

\begin{tabular}{|c|c|c|c|}
\hline Class & Application & Example of dye & \\
\hline Acid & $\begin{array}{l}\text { Silk, wool, leather, nylon, } \\
\text { modified acrylic fibers, ink, } \\
\text { paper }\end{array}$ & $\begin{array}{l}\text { Acid Yellow } 23 \\
\text { Acid Yellow } 36 \\
\text { Acid Red } 52 \\
\text { Acid Red } 88 \\
\text { Acid Black } 1 \\
\text { Acid Blue } 25 \\
\text { Acid Blue } 45 \\
\end{array}$ & $\begin{array}{l}\text { Congo Red } \\
\text { Allura Red } \\
\text { Erythrosine } \\
\text { Tartrazine } \\
\text { Sunset Yellow } \\
\text { Acid Orange } 3 \\
\text { Acid Orange } 19 \\
\end{array}$ \\
\hline $\begin{array}{l}\text { Basic/ } \\
\text { Cationic }\end{array}$ & $\begin{array}{l}\text { Leather, paper, wool, straw, } \\
\text { acrylics, silk, linen, hemp, } \\
\text { cotton, rayon, jute, modacrylic } \\
\text { fiber, coir }\end{array}$ & $\begin{array}{l}\text { Basic Brown } 1 \\
\text { Basic Violet } 10 \\
\text { Basic Violet } 14 \\
\text { Basic Blue } 9 \\
\text { Basic Blue } 54 \\
\text { Basic Violet } 3 \\
\text { Basic Green } 4 \\
\end{array}$ & $\begin{array}{l}\text { Basic Yellow } 2 \\
\text { Basic Yellow } 82 \\
\text { Methylene Blue } \\
\text { Toluidine Blue } \\
\text { Thionine } \\
\text { Crystal Violet } \\
\text { Basic Fuchsin Safranin }\end{array}$ \\
\hline Direct & $\begin{array}{l}\text { Cotton, paper, leather, wool, } \\
\text { silk, nylon, linen, rayon, } \\
\text { viscose }\end{array}$ & $\begin{array}{l}\text { Martius Yellow } \\
\text { Direct Yellow } 50 \\
\text { Direct Green } 28 \\
\text { Direct Orange } 26\end{array}$ & $\begin{array}{l}\text { Direct Red } 23 \\
\text { Direct Red } 81 \\
\text { Direct Blue } 67 \\
\text { Direct Black } 19\end{array}$ \\
\hline
\end{tabular}




\begin{tabular}{|c|c|c|c|}
\hline \multirow[t]{2}{*}{ Class } & \multirow[t]{2}{*}{ Application } & \multicolumn{2}{|l|}{ Example of dye } \\
\hline & & $\begin{array}{l}\text { Direct Orange } 28 \\
\text { Direct Violet } 51\end{array}$ & Direct Black 22 \\
\hline Disperse & $\begin{array}{l}\begin{array}{l}\text { Nylon, orlon, polyester, } \\
\text { cellulose acetate, triacetate } \\
\text { fibers, diacetate fibers, acrylic, } \\
\text { plastics }\end{array} \\
\text { Cotton, wool, silk, viscose, } \\
\text { nylon, polyamide fiber }\end{array}$ & $\begin{array}{l}\text { C.I. Basic Blue } 3 \\
\text { C.I. Basic Green } 4 \\
\text { Disperse Yellow } 3 \\
\text { Disperse Yellow } 49 \\
\text { Disperse Yellow } 126 \\
\text { Disperse Red } 4 \\
\text { Disperse Red } 54 \\
\text { Reactive Orange } 1 \\
\text { Reactive Orange } 86 \\
\text { Reactive Red } 5 \\
\text { Reactive Red } 2 \\
\text { Reactive Red } 11 \\
\end{array}$ & $\begin{array}{l}\text { Disperse Red } 134 \\
\text { Disperse Red } 202 \\
\text { Disperse Red } 210 \\
\text { Disperse Blue } 27 \\
\text { Disperse Blue } 73 \\
\text { Disperse Blue } 296 \\
\\
\text { Reactive Red } 6 \\
\text { Reactive Yellow } 22 \\
\text { Reactive Blue } 1 \\
\text { Reactive Blue } 5 \\
\text { Reactive Blue } 161 \\
\end{array}$ \\
\hline Vat & $\begin{array}{l}\text { Cotton, fibers, linen, rayon, } \\
\text { wool, silk, nylon, polyester }\end{array}$ & $\begin{array}{l}\text { Indigo } \\
\text { Vat Red } 10 \\
\text { Vat Blue } 4 \\
\text { Vat Blue } 36 \\
\text { Vat Blue } 64 \\
\text { Vat Brown } 3 \\
\text { Vat Brown } 45 \\
\text { Vat Violet } 13 \\
\text { Vat Violet } 18 \\
\end{array}$ & $\begin{array}{l}\text { Vat Orange } 1 \\
\text { Vat Orange } 3 \\
\text { Vat Orange } 17 \\
\text { Vat Green } 1 \\
\text { Vat Green } 11 \\
\text { Vat Green } 12 \\
\text { Vat Black } 25 \\
\text { Vat Black } 27 \\
\text { Vat Yellow } 28 \\
\end{array}$ \\
\hline Sulfur & Cotton, viscose, rayon & $\begin{array}{l}\text { Sulfur Red } 7 \\
\text { Sulfur Black 1 } \\
\text { Sulfur Yellow GC } \\
\text { Sulfur Brilliant Green } \\
\text { Sulfur Red Brown B3R } \\
\text { Sulfur Yellow Brown 6G } \\
\text { Thiazoles } \\
\text { Thianthrene } \\
\end{array}$ & $\begin{array}{l}\text { Sulphur Red } 10 \\
\text { Sulphur Blue } 10 \\
\text { Sulphur Black } 2 \\
\text { Sulphur Orange } 1 \\
\text { Sulphur Green } 14 \\
\text { Sulphur Yellow } 9 \\
\text { Sulphur Brown } 10\end{array}$ \\
\hline Mordant & $\begin{array}{l}\text { Wool, nylon, fiber, cotton, } \\
\text { silk, leather, anodized } \\
\text { aluminum }\end{array}$ & $\begin{array}{l}\text { Mordant Red } 5 \\
\text { Mordant Red } 11 \\
\text { Mordant Black } 11 \\
\text { Mordant Orange } 1 \\
\end{array}$ & $\begin{array}{l}\text { Turkey Red } \\
\text { Acid Orange } 10 \\
\text { Acid Mordant Orange } 14\end{array}$ \\
\hline Solvent & $\begin{array}{l}\text { Synthetics, plastics, gasoline, } \\
\text { oil, wax, vanish, lacquer, ink, } \\
\text { stain }\end{array}$ & $\begin{array}{l}\text { Solvent Red } 24 \\
\text { Solvent Red } 43 \\
\text { Solvent Red } 164 \\
\text { Solvent Blue } 35 \\
\text { Solvent Blue } 67 \\
\text { Solvent Green } 28 \\
\text { Solvent Orange } 2\end{array}$ & $\begin{array}{l}\text { Solvent Orange } 45 \\
\text { Solvent Yellow } 32 \\
\text { Solvent Yellow } 124 \\
\text { Solvent Violet } 31 \\
\text { Solvent Violet } 38 \\
\text { Solvent Black } 27 \\
\text { Solvent Brown } 43\end{array}$ \\
\hline
\end{tabular}

Table 2. Classification and example of dyes according to the chemical structure.

\begin{tabular}{|c|c|c|c|}
\hline Class & Structure/ & Example of dye & \\
\hline Azo & $-\mathrm{N}=\mathrm{N}-$ & $\begin{array}{l}\text { Procion Yellow H-EXL } \\
\text { Procion Navy H-EXL } \\
\text { Sulphonyl Blue TLE } \\
\text { Sulphonyl Green BLE } \\
\text { Maxilon Blue } \\
\text { Entrazol Blue IBC } \\
\text { BNLE }\end{array}$ & $\begin{array}{l}\text { Acid Red } 337 \\
\text { Congo red } \\
\text { Reactive Orange 16 } \\
\text { Reactive Black 5 } \\
\text { Remazol Black B } \\
\text { Remazol Black N } \\
\text { Sulphonyl Scarlet } \\
\end{array}$ \\
\hline Anthraquinone & & $\begin{array}{l}\text { Alizarin Red S } \\
\text { Uniblue } \\
\text { Reactive Blue } 4 \\
\text { Reactive Blue } 19 \\
\text { Remazol Brilliant Blue R } \\
\text { Pigment Yellow } 24\end{array}$ & $\begin{array}{l}\text { Vat Yellow } 28 \\
\text { Vat Green } 1 \\
\text { Acid Blue } 129 \\
\text { Acid Green 25 } \\
\text { Disperse Red 3B } \\
\text { Disperse Blue 3 } \\
\end{array}$ \\
\hline Triarylmethane & & $\begin{array}{l}\text { Acid Blue } 90 \\
\text { Acid Blue } 119 \\
\text { Acid Blue } 48 \\
\text { Patent Blue V } \\
\text { Brilliant Blue FCF } \\
\text { Basic Green } 4 \\
\text { Malachite Green }\end{array}$ & $\begin{array}{l}\text { Basic Red } 9 \\
\text { Basic Violet } 14 \\
\text { Basic Violet } 3 \\
\text { Basic Violet } 1 \\
\text { Basic Violet } 2 \\
\text { Green S }\end{array}$ \\
\hline
\end{tabular}




\begin{tabular}{l|l|l|l}
\hline Class & Example of dye & \\
\hline Heterocyclic & $\begin{array}{l}\text { Disperse Red 356 } \\
\text { Fluorol Yellow 88 } \\
\text { Solvent Green 4 } \\
\text { Basic Violet 10 }\end{array}$ & $\begin{array}{l}\text { Tyrian Purple } \\
\text { Thioindigo } \\
\text { Indigo Carmine }\end{array}$ \\
\hline Indigoid & $\begin{array}{l}\text { Acid Blue 71 } \\
\text { CI. Vat Blue 35 } \\
\text { CI. Basic Violet 14 }\end{array}$ & $\begin{array}{l}\text { Pigment Green B } \\
\text { CI. Pigment Green 8 }\end{array}$ \\
\hline Nitroso & $\begin{array}{l}\text { Martins Yellow } \\
\text { Palatine Orange } \\
\text { Fast Green O }\end{array}$ & $\begin{array}{l}\text { Martius Yellow } \\
\text { Naphthol Yellow }\end{array}$ \\
\hline Phthalein & & $\begin{array}{l}\text { Disperse Yellow 14 } \\
\text { CI. Acid Yellow 1 } \\
\text { CI. Pigment Yellow 11 }\end{array}$ & Phenolphthalein \\
\hline
\end{tabular}

\section{Toxicity effects of dyes}

Wastewater from dyeing industries is unarguably a huge pollutant around the world greatly because of the low ability of degradation and release of harmful substances as the dyes decompose. The release of dyeing effluents poses direct effects on water transparency, aesthetic merit as well as dissolved oxygen content. Furthermore, the water bodies contaminated by dyes usually contain high chemical oxygen demand (COD), biochemical oxygen demand (BOD), total dissolved solids (TDS), inorganic salts, $\mathrm{pH}$, turbidity, salinity and temperature [5]. These conditions are related to the incomplete degradation of dyes as the color from the dye wastewater impedes light penetration into the water bodies. The growth of biota was eventually interrupted as the photosynthetic activity is slowed down due to sunlight insufficiency. In addition, the foul smell was released to the atmosphere when the aquatic flora and fauna beneath the water surface are decomposing [6]. The discharge of dyeing effluents into the rivers induces soil infertility as the dye components are responsible for stabilizing and retaining the soils. As mentioned by Ajmal and Khan [7], a higher concentration of dye effluents used for irrigation has distinctly increased the delay and inhibition rates of seed germination as well as the overall growth of plants by observing the length of roots, shoots, dry weight of plants and the conditions of leaves. Even though new methods of reducing negative impacts on soil microbial pollutions such as organic amendments to soils were discovered, the effectiveness and post effects still remain unrecognized [8]. Thus, it is suggested to treat the contaminated wastewater before being released into the water bodies. Besides that, high content of chemicals, especially heavy metals such as cadmium, chromium, copper, lead, and nickel is often found in dyeing effluents. These heavy metals will bioaccumulate in the aquatic life and trapped in the soil, which was then be deposited into the human body through consumption [9]. Prolonged exposure to dye chemicals may contribute to the disruption of varied processing operations, which can cause serious health problems such as cancer, emphysema, heart diseases, kidney failure, and negative effects on metabolism. Based on a research done in 91 locations, more than 70 percent of the fish were detected with highly toxic dyes in their muscle tissues and has appeared to be an additional threat to some endangered 
species [10]. The occurrence of dyes not only poses health hazards to humans and aquatic plants but an environmental impact on the ecological balance.

\section{Current trend of dye wastewater treatment}

Textile industries involve the use of dye to colorize materials such as fabric; they are also the largest contributing factor to dye wastewaters. At the present time, the removal of dye particles from water sources has become a significant environmental concern, as well as a challenge such as dyes are extremely difficult to treat. This is due to the nature of dyes being stable molecules, produced primarily to resist degradation of light, various biological and chemical reactions. In addition, most dyes do not degrade naturally and require proper treatment prior to discharge. The treatment of dyeing effluent plays a vital role in ensuring safe water quality where the water will be recycled to the environment, then for industrial and domestic uses. Hence, effective and thorough technologies for textile wastewater treatment are essential to reduce environmental and health threats. A wide variety of dye removal techniques have been discovered in recent years and claimed to be successful dye remediations. Nevertheless, most of them suffer from drawbacks such as the ineffective removal against certain dyes or high cost of manufacturing [11]. The optimal method to eliminate dye from wastewater should be able to effectively extract large amounts of dye over a short time, without creating secondary pollution [12]. The classifications of dye removal technologies are divided into three groups, which are biological, chemical, and physical (Table 3).

Table 3. Advantages and disadvantages of biological, chemical, and physical methods for synthetic dye removal

\begin{tabular}{|c|c|c|}
\hline Treatment & $\begin{array}{c}{[17,44,45] .} \\
\text { Advantages }\end{array}$ & Disadvantages \\
\hline \multicolumn{3}{|l|}{ Biological methods } \\
\hline Activated sludge & $\begin{array}{ll}\text { - } & \text { Low cost of installation } \\
\text { - } & \text { Low requirement of land area }\end{array}$ & $\begin{array}{ll}\text { - } & \text { Generation of sludge } \\
\text { - } & \text { Rigid process method }\end{array}$ \\
\hline Fungal decolorization & $\begin{array}{ll}- & \text { Capable of degrading dyes using } \\
\text { enzymes } \\
\text { - } \quad \text { Flexible method }\end{array}$ & $\begin{array}{ll} & \text { Unreliable enzyme production } \\
\text { - } & \text { Lengthy growth phase }\end{array}$ \\
\hline $\begin{array}{l}\text { Microbial cultures } \\
\text { (Mixed bacterial) }\end{array}$ & $\begin{array}{l}\text { Decolourization occurs in } 23-30 \\
\text { hr which is considered fast }\end{array}$ & $\begin{array}{l}\text { - Cationic dyes are not ready for } \\
\text { metabolism under aerobic } \\
\text { conditions }\end{array}$ \\
\hline $\begin{array}{l}\text { Adsorption } \\
\text { (Microbial biomass) }\end{array}$ & $\begin{array}{ll} & \text { Some dyes bind to microbial } \\
\text { species with have high affinity }\end{array}$ & $\begin{array}{ll}\text { - } & \begin{array}{l}\text { Effective for a limited type of } \\
\text { dyes }\end{array}\end{array}$ \\
\hline Aerobic-anaerobic remediation & $\begin{array}{l}\text { Allow decolorization of azo and } \\
\text { water-soluble dyes } \\
\text { - No foam formation }\end{array}$ & $\begin{array}{ll}- & \text { Formation of hydrogen sulfide } \\
\text { - } & \text { Require a large land area } \\
- & \text { Generation of sludge } \\
- & \text { Time-consuming } \\
\end{array}$ \\
\hline Algae degradation & $\begin{array}{ll}- & \text { Easily assessable } \\
- & \text { Low operational cost } \\
\end{array}$ & - $\quad$ Unstable system \\
\hline Enzyme degradation & $\begin{array}{ll}- & \text { High efficiency } \\
- & \text { Non-toxic } \\
- & \text { Reusable } \\
\end{array}$ & - $\quad$ Unreliable enzyme production \\
\hline \multicolumn{3}{|l|}{ Chemical methods } \\
\hline Electrokinetic coagulation & - $\quad$ Economically expedient & - $\quad$ High generation of sludge \\
\hline Electrochemical destruction & $\begin{array}{ll}\text { - } & \text { Compounds broken down are } \\
\text { non-toxic } & \\
\text { - } & \text { No consumption of chemicals } \\
-\quad & \text { No sludge generation } \\
\end{array}$ & $\begin{array}{ll}- & \text { High electricity consumption } \\
\text { - } & \text { High flow rates cause a reduction } \\
\text { in dye removal }\end{array}$ \\
\hline Fenton's oxidation & $\begin{array}{ll}\text { - } & \text { Effective decolorization of } \\
\text { soluble and insoluble dyes } & \\
\text { - } & \text { Removal of all toxins }\end{array}$ & $\begin{array}{ll}- & \text { Generation of sludge } \\
- & \text { Narrow working pH range } \\
- & \text { High cost and risk with handling } \\
\text { reagents }\end{array}$ \\
\hline Ozonation & $\begin{array}{l}\text { - } \quad \text { Can be applied in a gaseous state } \\
\text { - No increase in sludge and } \\
\text { wastewater volume }\end{array}$ & $\begin{array}{ll}- & \text { Short half-life (20 mins) } \\
- & \text { Generation of toxic by-products } \\
- & \text { Unstable system }\end{array}$ \\
\hline
\end{tabular}




\begin{tabular}{|c|c|c|}
\hline Treatment & Advantages & Disadvantages \\
\hline \multicolumn{3}{|l|}{ Biological methods } \\
\hline & Fast reaction & High cost \\
\hline Ion exchange & $\begin{array}{ll}\text { - } & \begin{array}{l}\text { No loss of adsorbent during } \\
\text { regeneration }\end{array}\end{array}$ & $\begin{array}{l}\text { Effective for a limited type of } \\
\text { dyes }\end{array}$ \\
\hline Photochemical & $\begin{array}{ll}- & \text { Reduction in foul odors } \\
- & \text { No sludge generation }\end{array}$ & - Generation of by-products \\
\hline Sodium hypochlorite $(\mathrm{NaOCl})$ & $\begin{array}{l}\text { Initiates and accelerates azo-bond } \\
\text { cleavage }\end{array}$ & - $\quad$ Discharge of aromatic amines \\
\hline Ultraviolet irradiation & $\begin{array}{ll}- & \text { Require hazardous chemical } \\
- & \text { No sludge generation } \\
- & \text { Reduction in foul odors } \\
\end{array}$ & $\begin{array}{ll}- & \text { High cost } \\
- & \text { High energy consumption } \\
- & \text { Limited treatment times } \\
\end{array}$ \\
\hline \multicolumn{3}{|l|}{ Physical methods } \\
\hline $\begin{array}{l}\text { Adsorption } \\
\text { (Activated carbon) }\end{array}$ & $\begin{array}{l}\text { Effective removal of wide ranges of } \\
\text { dyes }\end{array}$ & $\begin{array}{l}\text { Very expensive } \\
15 \% \text { loss of sorbent upon reactivation }\end{array}$ \\
\hline $\begin{array}{l}\text { Adsorption } \\
\text { (Peat) }\end{array}$ & $\begin{array}{l}\text { Effective removal of wide ranges of } \\
\text { dyes }\end{array}$ & - $\quad$ Low surface area of adsorption \\
\hline $\begin{array}{l}\text { Adsorption } \\
\text { (Wood chips) }\end{array}$ & Effective removal of acid dyes & Require long retention time \\
\hline $\begin{array}{l}\text { Adsorption } \\
\text { (Silica gel) }\end{array}$ & Effective removal of basic dyes & $\begin{array}{l}\text { - Side reactions (air binding \& } \\
\text { fouling) prevent a commercial } \\
\text { application }\end{array}$ \\
\hline Membrane filtration & Effective for water recovery & $\begin{array}{ll}- & \text { High capital cost } \\
- & \text { Fouling of membrane } \\
\text { - } & \begin{array}{l}\text { Generation of concentrated } \\
\text { sludge }\end{array}\end{array}$ \\
\hline $\begin{array}{l}\text { Nano-filtration \& } \\
\text { Ultra-filtration }\end{array}$ & Effective removal of every type of dye & $\begin{array}{ll}- & \text { High electricity consumption } \\
\text { - } & \text { Require high pressure } \\
\text { - } & \text { Constant blockage of membrane } \\
& \text { pores } \\
\text { - } & \text { Short life span }\end{array}$ \\
\hline Reverse osmosis & $\begin{array}{lll}\begin{array}{l}\text { Effective } \\
\text { decolorization }\end{array} & \text { desalination } & \text { and } \\
\end{array}$ & $\begin{array}{ll}- & \text { High electricity consumption } \\
- & \text { Require high pressure }\end{array}$ \\
\hline Coagulation \& Flocculation & $\begin{array}{l}\text { Low cost } \\
\text { Effective removal of sulfur, vat and } \\
\text { disperse dyes }\end{array}$ & $\begin{array}{ll}\text { - } & \text { Large generation of concentrated } \\
\text { sludge } \\
\text { - } \quad \text { pH-dependent system }\end{array}$ \\
\hline
\end{tabular}

Biological treatment is often known as the most affordable green technique that eliminates organic dyes from textile wastewater with an optimum operating period, compared to chemical and physical remediations [13]. Examples of biologically based methods are activated sludge process, fungal decolorization, microbial cultures, adsorption, aerobicanaerobic remediation, algae, and enzyme degradation. Microorganisms such as algae, fungi, bacteria, and yeast are usually applied as biological materials to disintegrate, absorb, and accumulate dyes. It is notable that activated sludge treatment is capable of dealing with BOD and COD reduction [14] as well as removing more than $90 \%$ of dyes from the wastewater [15]. Dyes are designed to resist light-induced oxidative fading and chemical fading, such that they have fused aromatic ring, high water solubility, and molecular weight. These are the factors that cause dyes to be resilient to microbial degradation and restricted from permeation through biological cell membranes. Furthermore, some commercial dyes are hazardous to certain microorganisms, which will induce a distinct reduction in the biological degradation of dyes and result in sludge bulking. Generally, biological methods are not suitable to be applied to most textile effluents as they are unable to degrade complicated dyes, and the processes are time-consuming [16].

Chemical remediations are methods that apply chemistry and their theories to eliminate dyes. Chemical-based methods used to treat industrial dye effluents consist of electrokinetic coagulation, electrochemical destruction, Fenton's oxidation, ozonation, photochemical, and ion exchange. In comparison with biological and physical treatments for dye removal, chemical methods are more expensive, with an exception to electrochemical degradation [17]. For the 
treatment of wastewaters that are toxic to living biomass or immune to biological remediation, Fenton's reagent is a suitable chemical to be utilized [18]. Despite that, García-Montaño, Ruiz, Muñoz, Domènech, García-Hortal, Torrades, and Peral [19] mentioned that Fenton's oxidation is the least environmental-friendly dye removal process as it produces significant iron sludge through the flocculation of the reagent and dye particles. This is for the reason that cationic dyes are unable to coagulate at all, which will result in a poor quality of floc to be disposed of [11].

\section{Adsorption}

Adsorption through activated carbon has become a popular equilibrium separation technique due to its ability to produce high-quality treated effluent. Although activated carbon is an excellent adsorbent, it is also expensive, and hence, cheaper adsorbent alternatives such as peat, wood chips, and silica gel are developed. The basic types of membrane filtration processes in ascending order of allowable particle size are reverse osmosis, nano-filtration, ultrafiltration, and microfiltration. The filtration mechanisms of these operations are similar but can be differentiated by the relative size of particles being filtered and the pressure required to remove charged ion across the semi-permeable membranes [20]. This removal technique benefits from its resistance to temperature, microbial attack as well as the chemical environment. Nevertheless, membrane filtration requires a high capital cost on membrane replacement as the performance of a membrane drops over time and has a high possibility of clogging [11]. Besides that, the generation of thick residue poses disposal issues. Adsorption is the deposition of molecules at the interface of two phases, which can be liquid-solid, liquidgas, liquid-liquid, or gas-solid. For instance, the occurrence of adsorption in a solid-liquid system is capable of removing solutes from the solution and accumulating them at the solid surface [21]. Adsorption stands out as one of the most successful treatments in removing dye wastewaters. In recent years, not only the treatment of textile dye wastewaters has been using adsorption for treatment, large industrial companies that purify water from wastewater to drinking water uses the same technique as well. Due to the inability to remove dye from wastewaters through conventional methods, adsorption has become the most reliable treatment method. Initially, adsorption was not highly recommended due to the adsorbents being too expensive. However, researches and development these years have led to the discovery of low cost and high-efficiency adsorbents. Thus, it has become one of the most economical treatment methods in removing dye wastewaters [22]. There are many types of materials that can be used as adsorbents to treat dye wastewater, but the most general type is activated carbon.

\subsection{Types of activated carbon.}

Adsorption is the process of capturing pollutants known as adsorbate by attaching adsorbates on the adsorbent. Adsorbents are materials that have many insoluble sponge-like pores. A good adsorbent has characteristics such as high adsorption capacity, short adsorption period, size of adsorbent, and the pollutants that can be removed by the adsorbent [23]. The adsorbent capacity is based on the porosity of an adsorbent, and an increase in porous holes increased the total surface area in contact with adsorbates. The adsorption time required to treat wastewater should be shorter as the longer the time required, the lower the efficiency of the adsorbent. In addition, adsorbents that can remove various pollutants can help reduce the type of adsorbent required to treat different types of dye wastewater. However, the capacity is 
dependent on the type of carbonaceous source used. The lowest capacity of activated carbon is $500 \mathrm{mg} / \mathrm{g}$, while the highest capacity can reach up to $2000 \mathrm{mg} / \mathrm{g}$. One of the most well-known activated carbon is derived from coal. Many previous studies and researches had proved that coal-derived activated carbon has a high adsorbent capacity and can remove various types of dye from wastewaters. In addition, activated carbon can be beneficial as it can remove other pollutants such as heavy metals and organic and inorganic compounds. There are two sizes of activated carbon, that is microporous and macroporous. Microporous activated carbons are used to treat pollutants that have a molecule size smaller than $1 \mathrm{~nm}$. In contrast, macroporous activated carbon is used to treat larger sized molecules than are bigger than $1 \mathrm{~nm}$. In addition, there are two types of activated carbon. The two types of activated carbon are granular activated carbon (GAC) and powdered activated carbon (PAC). Generally, PAC is more advantageous as it is cheaper than GAC and has higher efficiency. This is because PAC has finer particles, which increases the total surface area in contact with the adsorbate. However, due to the fine particle size of PAC, it can be hard when it comes to designing equipment that can fully utilize PAC. Also, GAC and macroporous activated carbon are more suitable in treating dye as they have better dye adsorption ability [24-26].

\subsection{Activation of carbon.}

To obtain activated carbon, raw materials like coal and bamboo is treated under specific conditions. There are two types of activation, that is chemical activation and physical activation. The activation period for chemical activation is short, while the activation period for physical activation takes a long time. The activation of carbon through chemical activation is a one-step action. Raw materials are saturated with carbon activation chemicals such as potassium hydroxide and sodium hydroxide solution. The saturated chemical and raw materials are then simultaneously heated under the flow of nitrogen gas. After a short period of time, the raw materials are taken out and washed with distilled water to remove chemicals, and activated carbon is obtained. The advantage of chemical activation is that only a short period of time is required for the overall process, and the less activated carbon obtained is burnt. Physical activation of carbon requires two steps. The first step is pyrolysis, where raw materials are carbonized. The second step is the carbon activation of raw material with the use of steam or oxidation gases. The advantage of physical activation is the activated carbon obtained is macroporous in size, and they are suitable for dye wastewater treatment [27].

\subsection{Advantages and disadvantages of adsorption.}

The advantages of removal of dye through adsorption of activated carbon are that the efficiency is high. The success rate of removing dye by adsorption of activated carbon is $99.8 \%$. In addition, adsorption does not require large industrial area or processes which would require high maintenance and operation cost. The operation for adsorption is also easy and does not require high professional skills. During the process of activation of carbon also reduces unwanted waste as the raw materials used sometimes are unwanted waste. However, the disadvantage of adsorption is that activated carbon can become saturated to adsorb the pollutant and to decrease the ability after some time [28]. 


\section{Factors affecting adsorption}

The efficiency of adsorption is not only dependent on the type of adsorbent used but also on several other factors. Without proper handling and planning, adsorption can be inefficient as well. The most common factors that are affecting the efficiency of adsorbent are adsorbent dosage, contact time, $\mathrm{pH}$ value, dye concentration, and temperature. Any change in one of these factors would disturb the optimum working condition for the adsorbent.

\subsection{Adsorbent dosage.}

The efficiency of adsorption depends on the number of adsorbents used during the treatment process. An optimum number of adsorbents can be determined by preparing sample tests with a fixed concentration of dye and $\mathrm{pH}$ value. With optimum adsorbent dosage, then only can the efficiency be at maximum [29]. The removal rate of dye increases with increasing adsorbent dosage. This can also be explained as the increased mass of adsorbent provides a larger surface area, which enhances the adsorption process. This theory was supported by numerous studies focused on the effect of adsorbent dosage, and the results are demonstrated in Table 4.

Table 4. Effect of solution $\mathrm{pH}$ on the adsorption of RBBR and RBV-5R dyes by various biomass.

\begin{tabular}{l|c|c|c|c} 
Dye & Adsorbent & pH range & Removal (\%) & Reference \\
\hline RBBR & Pinecone & $2-13$ & $35-96$ & {$[46]$} \\
\hline & $\begin{array}{c}\text { Purging nut } \\
\text { Jatropha curcas) }\end{array}$ & $1-8$ & $40-95$ & \\
& $\begin{array}{c}\text { Pinang frond (Areca } \\
\text { catechu) }\end{array}$ & $3-11$ & $40-80$ & \\
\hline & Watermelon peel & $3-11$ & $31-71$ & \\
\hline & Corn peel & $3-11$ & $9-29$ & \\
\hline & Pomegranate peel & $2-12$ & $40-94$ & {$[47]$} \\
\hline & Peanut shell & $3-9$ & $84-100$ & {$[48]$} \\
\hline & White rot fungus & $3-7$ & $15-100$ & {$[49]$} \\
\hline & Cocoa pod husk & $3-11$ & $92-100$ & {$[35]$} \\
\hline & Orange peel & $2-6$ & $69-90$ & {$[50]$} \\
\hline & Chicken eggshell & $2-11$ & $55-94$ & {$[51]$} \\
\hline & Calcined eggshell & $3-11$ & $96-97$ & {$[52]$} \\
\hline & Sawdust & $1-6$ & $10-85$ & {$[53]$} \\
\hline & Coconut mesocarp & $1-6$ & $8-85$ & {$[53]$} \\
\hline & Natura rice hull & $1-6$ & $15-46$ & {$[54]$} \\
\hline & Treated rice hull & $1-6$ & $60-74$ & {$[54]$} \\
\hline & Watermelon peel & $3-11$ & $39-68$ & \\
\hline & Corn peel & $3-11$ & $14-44$ &
\end{tabular}

\section{2. $p H$ value.}

The $\mathrm{pH}$ value controls the movement of the electrostatic charge. The rate of transmission of the dye molecules from the wastewater to the adsorbent varies depending on the degree of electrostatic charge. The optimum $\mathrm{pH}$ value for adsorption is near to 6 , which is slightly below neutral [29]. A previous study showed that high $\mathrm{pH}$ value causes a change at the solution interface, inducing the adsorbent surface to be negatively charged. Thus, the electrostatic repulsion of negatively charged functional groups of reactive dyes from the adsorbent surface will eventually decrease the rate of adsorption [30]. On the contrary, solutions with low $\mathrm{pH}$ content enhance the attraction forces between the molecules of reactive dye and adsorbent surface. This phenomenon will then allow the rate of anionic adsorption to 
increase [31]. The results of various studies on the effect of $\mathrm{pH}$ content with different adsorbents are tabulated in Table 5 .

Table 5. Effect of initial dye concentration on the adsorption of RBBR and RBV-5R dyes by various biomass.

\begin{tabular}{l|l|l|l|l} 
Dye & Adsorbent & Concentration range $(\mathbf{m g} / \mathbf{L})$ & Removal $(\mathbf{\%})$ & Reference \\
\hline RBBR & Pinecone & 200 & $48-98$ & {$[46]$} \\
\hline & Jatropha curcas pods & $50-250$ & $48-94$ & {$[55]$} \\
\hline & Watermelon peel & $30-50$ & $64-48$ & \\
\hline & Corn peel rot fungus & $30-50-3000$ & $11.4-11.5$ & \\
\hline & $\begin{array}{l}\text { White squalens) } \\
\text { (Dichomitus squen }\end{array}$ & & $94-95$ & {$[56]$} \\
\hline RBV-5R & Cocoa pod husk & $20-100$ & & \\
\hline & Chicken eggshell & $20-100$ & $76-97$ & {$[35]$} \\
\hline & Calcined eggshell & $20-100$ & $72-88$ & {$[51]$} \\
\cline { 2 - 4 }
\end{tabular}

\subsection{Dye concentration.}

A higher concentration of dye would require a much larger adsorbent. The number of binding sites for the dye molecules to attach to the adsorbent would need to be increased in order to fully remove high concentrated dye from the solution [17]. The initial concentration of dye plays a significant role in resolving the mass transfer resistance of the dye in both solid and aqueous states. Mahmoud, Salleh, Karim, Idris and Abidin [32] states that high adsorption capacity can be achieved if the initial concentration of dye is high. This is due to the strong driving force provided to the concentration gradient. Nevertheless, the percentage of color removal will decrease as the initial dye concentration increases as the majority of binding sites of adsorbents are occupied [33]. Table 6 shows the effect of initial dye concentration on dye adsorption by various adsorbents.

Table 6. Effect of temperature on the adsorption of RBBR and RBV-5R dyes by various biomass.

\begin{tabular}{l|c|c|c|c} 
Dye & Adsorbent & $\begin{array}{c}\text { Temperature range } \\
\left({ }^{\circ} \mathbf{C}\right)\end{array}$ & Removal (\%) & Reference \\
\hline RBBR & Pinecone & $25-45$ & $61.5-94.6$ & {$[46]$} \\
\hline & Peanut shell & $20-60$ & $52-100$ & {$[48]$} \\
\hline RBV-5R & White rot fungus & $4-60$ & $15-100$ & {$[49]$} \\
\hline & Chicken eggshell & $20-0$ & $90-94$ & {$[51]$} \\
\hline & Calcined eggshell & $20-40$ & $89-97$ & {$[52]$}
\end{tabular}

\subsection{Temperature.}

Temperature affects the treatment process by the shifting of nature of reaction from endothermic to exothermic or vice versa. The rate of adsorption drops when the temperature is too high or low. The optimum temperature is tested to be around $30^{\circ} \mathrm{C}$ [17]. Adsorption reactions are usually indicated as exothermic processes as heat energy is being released to the surroundings [34]. An increase of temperature improves the adsorption capacity by enhancing the rate of diffusion of adsorbate molecules across the external boundary layer caused by the low viscosity of the solution [35]. This may also be a result of the rising number of active sites in the adsorbent surfaces, as well as the enhanced mobility of the dye molecules at higher temperatures [36]. However, the adsorption rate will decrease after some time when the temperature has achieved its equilibrium [37]. Table 7 indicates the results from several studies on the effect of temperature with different adsorbents. 
Table 7. Effect of adsorbent dosage on the adsorption of RBBR and RBV-5R dyes by various biomass.

\begin{tabular}{l|c|c|c|c} 
Dye & Adsorbent & $\begin{array}{c}\text { Adsorbent dosage } \\
(\mathbf{g})\end{array}$ & Removal (\%) & Reference \\
\hline RBBR & Pinecone & $0.5-2.0$ & $48-98$ & {$[46]$} \\
\hline & Jatropha curcas pods & $0.1-0.5$ & $62-98$ & {$[55]$} \\
\hline RBV5R & Tea leaves & 5 & 11 & {$[57]$} \\
\hline & Orange peel & $0.05-2$ & $25-80$ & {$[50]$} \\
\hline & Chicken eggshell & $0.5-2.5$ & $75-95$ & {$[51]$} \\
\hline & Calcined eggshell & $0.5-2.0$ & $90-97$ & {$[52]$}
\end{tabular}

\section{Utilization of agricultural biomass and future development}

The challenges for coal-derived activated carbon is a limited resource due to the limited availability of fossil fuel. Industries cannot fully rely on the usage of coal activated carbon. In addition, adsorption beds become weaker as time passes. The efficiency drops due to the dye removal rate become weaker, and the adsorbent capacity decreases [38]. Adsorption on activated carbon has been widely applied in wastewater treatment industries as it is regarded as a highly efficient process. Nevertheless, the high production and regeneration cost of activated carbon, as well as its effect, which may produce other pollutants, has prompted researchers to develop cheaper alternatives [39]. A number of waste materials are being studied especially agricultural biomass as it has little or no economic value and often poses disposal issues. Some low-cost agricultural biomass-based adsorbents such as tea waste, hazelnut husk, bacteria aggregate, rice ash, pineapple leaf, and fruit waste have been tested to be effective in dye removal process [40]. Used activated carbon would have fewer active pores to trap adsorbates as well. However, technologies nowadays have found a way to regenerate the adsorbent, allowing it to be used again [41]. Other than that, the development of activated carbon derived from renewable materials has been studied thoroughly in recent years. A renewable resource such as biomass and specific wastes has been put to research and to activate carbon. Studies found that the cost of using renewable resource derived activated carbon can be cheaper than coal-derived activated carbon [42]. In addition, deriving activated carbon from wastes can also help reduce current unwanted wastes and further protect the environment. Furthermore, the cost to develop activated carbon from waste is rather cheap, making it a viable treatment option nowadays. Moreover, scientists have found new treatment methods involving adsorption with biological treatment processes. Bio-adsorption is a combination of a biological method using biomass such as agricultural waste with adsorption. The adsorption capacity and sustainability are better than normal adsorption [43]. However, the tests carried out are on a laboratory scale. The difficulty in advancing this treatment to industrial-sized is because of the high utilization cost. It should be further studied such that a more economical treatment method can be found. There are mainly four categories of agricultural biomass-derived adsorbent, such as leaf-based, peel-based, stem-based, and seed-based adsorbents. The percentage of color removal by various agricultural biomass-based adsorbent are tabulated in Table 8 .

Table 8. Various plant biomass as an adsorbent for RBBR and RBV-5R dye removal.

\begin{tabular}{l|l|l|l|l} 
Dye & Adsorbent & Plant parts & Removal (\%) & Reference \\
\hline \multirow{2}{*}{ RBBR } & Xanthium italicum & leaf & 95 & {$[58]$} \\
\cline { 2 - 5 } & Tea leaves & leaf & 11.39 & {$[57]$} \\
\cline { 2 - 5 } & Mangosteen peel & peel & 80.35 & {$[59]$} \\
\cline { 2 - 5 } & Orange peel & peel & 14.92 & {$[57]$} \\
\cline { 2 - 5 } & Rambutan peel & peel & $40.5-90.3$ & {$[57]$} \\
\cline { 2 - 5 } & Pomegranate peel & peel & 81.35 & {$[60]$} \\
\cline { 2 - 5 } & Watermelon rind & peel & $41.8-97.2$ & {$[61]$} \\
\cline { 2 - 5 } & Pinecone & seed & $48-98$ & {$[62]$} \\
\cline { 2 - 4 }
\end{tabular}




\begin{tabular}{l|l|l|l|l}
\hline \multirow{2}{*}{ Dye } & Adsorbent & Plant parts & Removal (\%) & Reference \\
\hline \multirow{2}{*}{ Orange peel } & peel & $75-80$ & {$[63]$} \\
\cline { 2 - 5 } & Bagassa guianensis Aubl & stem & $10-85$ & {$[53]$} \\
\cline { 2 - 5 } & Coconut mesocarp & seed & $8-85$ & {$[53]$} \\
\cline { 2 - 4 } & Cocoa pod husk & seed & $92-100$ & {$[35]$}
\end{tabular}

\section{Conclusions}

To conclude, it is essential to develop an effective treatment method on dye wastewaters such that the environment is not damaged or disturbed. Although there are many types of treatment methods, not all are viable options. The limited source of funding can be a major problem as dye wastewater treatment is a complex process. Some equipment required can be expensive. Furthermore, without proper planning and treatment process, and inefficient treatment method could be wasteful. Thus, adsorption using activated carbon becomes a better choice for removing dye from wastewater. Adsorption mainly uses the porous sponge-like holes in activated carbons to trap and capture dye molecules. Factors such as $\mathrm{pH}$ value, dye concentration, temperature, adsorbent dosage, and contact time should be measured properly such that the removal rate can be optimized. In adsorption, the most efficient type of activated carbon is coal-derived activated carbon. The efficiency of treatment is $99.8 \%$, and it can treat various types of dyes and even heavy metals. The regeneration of activated carbon can be done to renew the adsorption capacity of the activated carbon such that less adsorbent would be disposed of. However, the disposal of adsorbents is not discussed in this paper. Therefore, more research is to be conducted on how to dispose of unwanted adsorbent in case of regeneration or reactivation failure of the adsorbent. The consequences of disposing of adsorbent should also be taken into consideration such that no environmental damage is done.

\section{Funding}

This research received no external funding.

\section{Acknowledgments}

This research has no acknowledgment.

\section{Conflicts of Interest}

The authors declare no conflict of interest.

\section{References}

1. Balasuriya, A. Chapter 25 - Coastal Area Management: Biodiversity and Ecological Sustainability in Sri Lankan Perspective. In: Biodiversity and Climate Change Adaptation in Tropical Islands. Sivaperuman, C.; Velmurugan, A.; Singh, A.K.; Jaisankar, I. (eds) Academic Press, 2018; https://doi.org/10.1016/C2016-004301-2.

2. Hao, X.; Chen, G.; Yuan, Z.: Water in China. Water Research 2020, 169, https://doi.org/10.1016/j.watres.2019.115256.

3. Gurr, E. Synthetic dyes in biology, medicine and chemistry. Elsevier, 2012; https://doi.org/10.1016/B978-0123-09650-0.X5001-7.

4. Tkaczyk, A.; Mitrowska, K.; Posyniak, A. Synthetic organic dyes as contaminants of the aquatic environment and their implications for ecosystems: A review. Science of The Total Environment 2020, 717, 137222, https://doi.org/10.1016/j.scitotenv.2020.137222.

5. Millington, K.R. 9 - Improving the whiteness and photostability of wool. In: Advances in Wool Technology. Johnson, N.A.G.; Russell, I.M. (eds) Woodhead Publishing, 2009; https://doi.org/10.1533/9781845695460.2.217. 
6. Lafi, R.; Gzara, L.; Lajimi, R.H.;Hafiane, A. Treatment of textile wastewater by a hybrid ultrafiltration/electrodialysis process. Chemical Engineering and Processing - Process Intensification 2018, 132, 105-113, https://doi.org/10.1016/j.cep.2018.08.010.

7. Garg, V.K.; Amita, M.; Kumar, R.; Gupta, R. Basic dye (methylene blue) removal from simulated wastewater by adsorption using Indian Rosewood sawdust: a timber industry waste. Dyes and Pigments 2004, 63, 243-250, https://doi.org/10.1016/j.dyepig.2004.03.005.

8. Ajmal, M.; Khan, A.U. Effects of a textile factory effluent on soil and crop plants. Environmental Pollution Series A, Ecological and Biological 1985, 37, 131-148, https://doi.org/10.1016/0143-1471(85)90004-2.

9. Rehman, K.; Shahzad, T.; Sahar, A.; Hussain, S.; Mahmood, F.; Siddique, M.H.; Siddique, M.A.;Rashid, M.I. Effect of Reactive Black 5 azo dye on soil processes related to $\mathrm{C}$ and N cycling. PeerJ 2018, 6, 48024802, https://doi.org/10.7717/peerj.4802.

10. Sungur, Ş.; Gülmez, F. Determination of Metal Contents of Various Fibers Used in Textile Industry by MPAES. Journal of Spectroscopy 2015, 2015, https://doi.org/10.1155/2015/640271.

11. Belpaire, C.; Reyns, T.; Geeraerts, C.; Van Loco, J. Toxic textile dyes accumulate in wild European eel Anguilla anguilla. Chemosphere 2015, 138, 784-791, https://doi.org/10.1016/j.chemosphere.2015.08.007.

12. Robinson, T.; McMullan, G.; Marchant, R.; Nigam, P. Remediation of dyes in textile effluent: a critical review on current treatment technologies with a proposed alternative. Bioresource Technology 2001, 77, 247-255, https://doi.org/10.1016/S0960-8524(00)00080-8.

13. Rodríguez-Couto, S.; Osma, J.F.; Toca-Herrera, J.L. Removal of synthetic dyes by an eco-friendly strategy. Engineering in Life Sciences 2009, 9, 116-123, https://doi.org/10.1002/elsc.200800088.

14. Bhatia, D.; Sharma, N.; Singh, J.; Kanwar, R. Biological methods for textile dye removal from wastewater: A Review. Critical Reviews in Environmental Science and Technology 2017, 47, 1836-1876, https://doi.org/10.1080/10643389.2017.1393263.

15. Banat, I.M.; Nigam, P.; Singh, D.; Marchant, R. Microbial decolorization of textile-dyecontaining effluents: A review. Bioresource Technology 1996, 58, 217-227, https://doi.org/10.1016/S0960-8524(96)00113-7.

16. Makwana, A. Optimization of activated sludge process system for dye wastewater. International Journal of Engineering Sciences \& Research Technology 2017, 6, 774-778, https://doi.org/10.5281/zenodo.569959.

17. Can, O.T.; Kobya, M.; Demirbas, E.; Bayramoglu, M. Treatment of the textile wastewater by combined electrocoagulation. Chemosphere 2006, 62, 181-187, https://doi.org/10.1016/j.chemosphere.2005.05.022.

18. Katheresan, V.; Kansedo, J.; Lau, S.Y. Efficiency of various recent wastewater dye removal methods: A review. Journal of Environmental Chemical Engineering 2018, 6, 4676-4697, https://doi.org/10.1016/j.jece.2018.06.060.

19. Slokar, Y.M.; Majcen Le Marechal, A. Methods of decoloration of textile wastewaters. Dyes and Pigments 1998, 37, 335-356, https://doi.org/10.1016/S0143-7208(97)00075-2.

20. García-Montaño, J.; Ruiz, N.; Muñoz, I.; Domènech, X.; García-Hortal, J.A.; Torrades, F.; Peral, J. Environmental assessment of different photo-Fenton approaches for commercial reactive dye removal. Journal of Hazardous Materials 2006, 138, 218-225, https://doi.org/10.1016/j.jhazmat.2006.05.061.

21. Sahai, R. Membrane Separation | Filtration. In: Encyclopedia of Separation Science. Wilson, I.D. (ed) Academic Press, 2000, Oxford.

22. De Gisi, S.; Lofrano, G.; Grassi, M.; Notarnicola, M. Characteristics and adsorption capacities of low-cost sorbents for wastewater treatment: A review. Sustainable Materials and Technologies 2016, 9, 10-40, https://doi.org/10.1016/j.susmat.2016.06.002.

23. Ngulube, T.; Gumbo, J.R.; Masindi, V.; Maity, A. An update on synthetic dyes adsorption onto clay based minerals: A state-of-art review. Journal of Environmental Management 2017, 191, 35-57, https://doi.org/10.1016/j.jenvman.2016.12.031.

24. Park, J.H.;Park, S.J. Expansion of effective pore size on hydrogen physisorption of porous carbons at low $\begin{array}{llllll}\text { temperatures with } \quad \text { high } & \text { 2020, }\end{array}$ https://doi.org/10.1016/j.carbon.2019.10.100.

25. Abdi, J.; Vossoughi, M.; Mahmoodi, N.M.; Alemzadeh, I. Synthesis of metal-organic framework hybrid nanocomposites based on GO and CNT with high adsorption capacity for dye removal. Chemical Engineering Journal 2017, 326, 1145-1158, https://doi.org/10.1016/j.cej.2017.06.054.

26. Khori, N.K.E.M.; Hadibarata, T.; Elshikh, M.S.; Al-Ghamdi, A.A.; Salmiati; Yusop, Z. Triclosan removal by adsorption using activated carbon derived from waste biomass: Isotherms and kinetic studies. Journal of the Chinese Chemical Society 2018, 65, 951-959, https://doi.org/10.1002/jccs.201700427.

27. Kristanti, R.A.; Hadibarata, T.; Al Qahtani, H.M.S. Adsorption of bisphenol a on oil palm biomass activated carbon: Characterization, isotherm, kinetic and thermodynamic studies. Biointerface Research in Applied Chemistry 2019, 9, 4217-4224, https://doi.org/10.33263/BRIAC95.217224.

28. Wirasnita, R.; Hadibarata, T.; Yusoff, A.R.M.;Yusop, Z. Removal of Bisphenol A from Aqueous Solution by Activated Carbon Derived from Oil Palm Empty Fruit Bunch. Water, Air, \& Soil Pollution 2014, 225, https://doi.org/10.1007/s11270-014-2148-x.

29. Lata, S.; Singh, P.K.;Samadder, S.R. Regeneration of adsorbents and recovery of heavy metals: a review. International Journal of Environmental Science and Technology 2015, 12, 1461-1478, https://doi.org/10.1007/s13762-014-0714-9. 
30. Yagub, M.T.; Sen, T.K.; Afroze, S.; Ang, H.M. Dye and its removal from aqueous solution by adsorption: A review. Advances in Colloid and Interface Science 2014, 209, 172-184, https://doi.org/10.1016/j.cis.2014.04.002.

31. Santhy, K.; Selvapathy, P. Removal of reactive dyes from wastewater by adsorption on coir pith activated carbon. Bioresource Technology 2006, 97, 1329-1336, https://doi.org/10.1016/j.biortech.2005.05.016.

32. Demirbas, E.; Nas, M.Z. Batch kinetic and equilibrium studies of adsorption of Reactive Blue 21 by fly ash and sepiolite. Desalination 2009, 243, 8-21, https://doi.org/10.1016/j.desal.2008.04.011.

33. Mahmoud, D.K.; Salleh, M.A.M.; Karim, W.A.W.A.; Idris, A.; Abidin, Z.Z. Batch adsorption of basic dye using acid treated kenaf fibre char: Equilibrium, kinetic and thermodynamic studies. Chemical Engineering Journal 2012, 181-182, 449-457, https://doi.org/10.1016/j.cej.2011.11.116.

34. Tunç, Ö.; Tanac1, H.; Aksu, Z. Potential use of cotton plant wastes for the removal of Remazol Black B reactive dye. Journal of Hazardous Materials 2009, 163, 187-198, https://doi.org/10.1016/j.jhazmat.2008.06.078.

35. Nandi, B.K.; Goswami, A.; Purkait, M.K. Removal of cationic dyes from aqueous solutions by kaolin: Kinetic and equilibrium studies. Applied Clay Science 2009, 42, 583-590, https://doi.org/10.1016/j.clay.2008.03.015.

36. Bello, O.S.; Siang, T.T.; Ahmad, M.A. Adsorption of Remazol Brilliant Violet-5R reactive dye from aqueous solution by cocoa pod husk-based activated carbon: kinetic, equilibrium and thermodynamic studies. AsiaPacific Journal of Chemical Engineering 2012, 7, 378-388, https://doi.org/10.1002/apj.557.

37. Ofomaja, A.E.; Ho, Y.S. Equilibrium sorption of anionic dye from aqueous solution by palm kernel fibre as sorbent. Dyes and Pigments 2007, 74, 60-66, https://doi.org/10.1016/j.dyepig.2006.01.014.

38. Senthilkumaar, S.; Kalaamani, P.; Subburaam, C.V. Liquid phase adsorption of Crystal violet onto activated carbons derived from male flowers of coconut tree. Journal of Hazardous Materials 2006, 136, 800-808, https://doi.org/10.1016/j.jhazmat.2006.01.045.

39. Ballav, N.; Das, R.; Giri, S.; Muliwa, A.M.; Pillay, K.; Maity, A. 1-cysteine doped polypyrrole (PPy@LCyst): A super adsorbent for the rapid removal of $\mathrm{Hg}+2$ and efficient catalytic activity of the spent adsorbent for reuse. Chemical Engineering Journal 2018, 345, 621-630, https://doi.org/10.1016/j.cej.2018.01.093.

40. Bharathi, K.S.; Ramesh, S.T. Removal of dyes using agricultural waste as low-cost adsorbents: a review. Applied Water Science 2013, 3, 773-790, https://doi.org/10.1007/s13201-013-0117-y.

41. Ansari, S.A.; Khan, F.; Ahmad, A. Cauliflower Leave, an Agricultural Waste Biomass Adsorbent, and Its Application for the Removal of MB Dye from Aqueous Solution: Equilibrium, Kinetics, and Thermodynamic Studies. International Journal of Analytical Chemistry 2016, 2016, https://doi.org/10.1155/2016/8252354.

42. Rafatullah, M.; Sulaiman, O.; Hashim, R.; Ahmad, A. Adsorption of methylene blue on low-cost adsorbents: A review. Journal of Hazardous Materials 2010, 177, 70-80, https://doi.org/10.1016/j.jhazmat.2009.12.047.

43. Cui, M.H.; Sangeetha, T.; Gao, L.;Wang, A.J. Efficient azo dye wastewater treatment in a hybrid anaerobic reactor with a built-in integrated bioelectrochemical system and an aerobic biofilm reactor: Evaluation of the combined forms and reflux ratio. Bioresource Technology 2019, 292, https://doi.org/10.1016/j.biortech.2019.122001.

44. Sathishkumar, K.; AlSalhi, M.S.; Sanganyado, E.; Devanesan, S.; Arulprakash, A.; Rajasekar, A. Sequential electrochemical oxidation and bio-treatment of the azo dye congo red and textile effluent. Journal of Photochemistry and Photobiology B: Biology 2019, 200, https://doi.org/10.1016/j.jphotobiol.2019.111655.

45. Yildiz, B.S. 18 - Water and wastewater treatment: biological processes. In: Zeman F, (ed) Metropolitan Sustainability Woodhead Publishing, 2012.

46. Geçgel, U.; Kolancılar, H. Adsorption of Remazol Brilliant Blue R on activated carbon prepared from a pine cone. Natural product research 2011, 26, 659-664, https://doi.org/10.1080/14786419.2010.541878.

47. Sathishkumar, P.; Arulkumar, M.; Palvannan, T. Utilization of agro-industrial waste Jatropha curcas pods as an activated carbon for the adsorption of reactive dye Remazol Brilliant Blue R (RBBR). Journal of Cleaner Production 2012, 22, 67-75, https://doi.org/10.1016/j.jclepro.2011.09.017.

48. Ahmad, M.A.; Ahmad Puad, N.A.; Bello, O.S. Kinetic, equilibrium and thermodynamic studies of synthetic dye removal using pomegranate peel activated carbon prepared by microwave-induced KOH activation. Water Resources and Industry 2014, 6, 18-35, https://doi.org/10.1016/j.wri.2014.06.002.

49. Bilir, M.; Şakalar, N.; Acemioğlu, B.; Baran, E.; Mehmet, A. Sorption of remazol brilliant blue R onto polyurethane-type foam prepared from peanut shell. Journal of Applied Polymer Science 2013, 127, https://doi.org/10.1002/app.37614.

50. Hadibarata, T.; Tachibana, S. Decolorization of Remazol Briliant Blue R by Laccase from White Rot Fungus Polyporus sp. S133. Indonesian Journal of Biotechnology 2009, 14, 1162-1168, https://doi.org/10.22146/ijbiotech.7811.

51. Hashemian, S.; Salari, K.; Salehifar, H.;Yazdi, Z. Removal of Azo Dyes (Violet B and Violet 5R) from Aqueous Solution Using New Activated Carbon Developed from Orange Peel. Journal of Chemistry 2013, 2013, 1-10, https://doi.org/10.1155/2013/283274. 
52. Rápó, E.; Aradi, L.E.; Szabó, Á.; Posta, K.; Szép, R.;Tonk, S. Adsorption of Remazol Brilliant Violet-5R Textile Dye from Aqueous Solutions by Using Eggshell Waste Biosorbent. Scientific Reports 2020, 10, https://doi.org/10.1038/s41598-020-65334-0.

53. Rápó, E.; Posta, K.; Suciu, M.; Szép, R.;Tonk, S. Adsorptive Removal of Remazol Brilliant Violet-5R Dye from Aqueous Solutions using Calcined Eggshell as Biosorbent. Acta Chimica Slovenia 2019, 66, https://doi.org/10.17344/acsi.2019.5079.

54. Monteiro, M.S.; de Farias, R.F.; Chaves, J.A.P.; Santana, S.A.; Silva, H.A.S.; Bezerra, C.W.B. Wood (Bagassa guianensis Aubl) and green coconut mesocarp (cocos nucifera) residues as textile dye removers (Remazol Red and Remazol Brilliant Violet). Journal of Environmental Management 2017, 204, 23-30, https://doi.org/10.1016/j.jenvman.2017.08.033.

55. Ribeiro, G.A.C.; Silva, D.S.A.; Santos, C.C.D.; Vieira, A.P.; Bezerra, C.W.B.; Tanaka, A.A.; Santana, S.A.A. Removal of Remazol brilliant violet textile dye by adsorption using rice hulls. Polímeros 2017, 27, 16-26, https://doi.org/10.1590/0104-1428.2386.

56. Eichlerová, I.; Homolka, L.; Benada, O.; Kofroňová, O.; Hubálek, T.; Nerud, F. Decolorization of Orange $\mathrm{G}$ and Remazol Brilliant Blue R by the white rot fungus Dichomitus squalens: Toxicological evaluation and morphological study. Chemosphere 2007, 69, 795-802, https://doi.org/10.1016/j.chemosphere.2007.04.083.

57. Lazim, Z.M.; Mazuin, E.; Hadibarata, T.;Yusop, Z. The removal of methylene blue and Remazol Brilliant Blue R dyes by using orange peel and spent tea leaves. Jurnal Teknologi 2015, 74, 129-135.

58. Saleh, M.; Yalvaç, M.; Arslan, H. Optimization of Remazol Brilliant Blue R Adsorption onto Xanthium Italicum using the Response Surface Method. Karbala International Journal of Modern Science 2019, 5 , https://doi.org/10.33640/2405-609X.1017.

59. Azmier, M.; Alrozi, R. Optimization of preparation conditions for mangosteen peel-based activated carbons for the removal of Remazol Brilliant Blue R using response surface methodology. Chemical Engineering Journal 2010, 165, 883-890, https://doi.org/10.1016/j.cej.2010.10.049.

60. Ahmad, M.; Eusoff, M.; Oladoye, P.; Adesina Adegoke, K.; Bello, O. Statistical Optimization of Remazol Brilliant Blue R Dye Adsorption onto Activated Carbon Prepared from Pomegranate Fruit Peel. Chemical Data Collections 2020, https://doi.org/10.1016/j.cdc.2020.100426.

61. Ahmad, M.A.; Ahmad, N.; Bello, O.S. Removal of Remazol Brilliant Blue Reactive Dye from Aqueous Solutions Using Watermelon Rinds as Adsorbent. Journal of Dispersion Science and Technology 2015, 36, 845-858, https://doi.org/10.1080/01932691.2014.925400.

62. Krueger, M.; Volkmann, A.; Rainert, K. Removal of textile dye Remazol Brilliant Blue Reactive (RBBR) using fibers of Citrullus lanatus (watermelon) and Cocos nucifera (green coconut) as adsorbent material. Revista Eletrônica em Gestão, Educação e Tecnologia Ambiental 2019, 23, https://doi.org/10.5902/2236117038526.

63. Anastopoulos, I.; Kyzas, G.Z. Agricultural peels for dye adsorption: A review of recent literature. Journal of Molecular Liquids 2014, 200, 381-389, https://doi.org/10.1016/j.molliq.2014.11.006. 